Article

\title{
Implementing Strategic Sustainable Supply Chain Management
}

\author{
Cecilia Bratt ${ }^{1}$, Robert Sroufe ${ }^{2, *}$ (D) and Göran Broman ${ }^{1}$ \\ 1 Department of Strategic Sustainable Development, Faculty of Engineering, Blekinge Institute of Technology, \\ 37179 Karlskrona, Sweden; cecilia.bratt@bth.se (C.B.); goran.broman@bth.se (G.B.) \\ 2 MBA Sustainable Business Practices Program, Management Department, Donahue School of Business, \\ Duquesne University, Pittsburgh, PA 15238, USA \\ * Correspondence: sroufer@duq.edu
}

Citation: Bratt, C.; Sroufe, R.; Broman, G. Implementing Strategic Sustainable Supply Chain Management. Sustainability 2021, 13, 8132. https://doi.org/10.3390/ su13158132

Academic Editor: Yoshiki Shimomura

Received: 18 June 2021

Accepted: 14 July 2021

Published: 21 July 2021

Publisher's Note: MDPI stays neutral with regard to jurisdictional claims in published maps and institutional affiliations.

Copyright: (c) 2021 by the authors. Licensee MDPI, Basel, Switzerland. This article is an open access article distributed under the terms and conditions of the Creative Commons Attribution (CC BY) license (https:// creativecommons.org/licenses/by/ $4.0 /)$.

\begin{abstract}
Despite increasing business interest in sustainability in general and in sustainable supply chain management (SSCM), the ability to increase suppliers' ecological and social performance is generally insufficient for many companies. In this study, we outline an implementation process model for sustainable supply chain management. We do so by synthesizing insights from a review of the sustainable supply chain management and organizational learning literature and a case study with a company aspiring to become a global leader in sustainable lighting. By combining these insights, we find that successful implementation of sustainable supply chain management requires sustainability to be anchored in a company's vision and integrated into all functions. We also argue that organizational learning, especially learning with external stakeholders such as suppliers, an operational definition of socioecological sustainability among stakeholders, and procedural support for the cocreation of strategic plans for change are vital for achieving a truly sustainable supply chain. This definition and cocreation allow for attention to be directed toward strategic ecological and social practices, along with the joint handling of tradeoffs and economic considerations among stakeholders. As we build a foundation for an SSCM implementation process model, we use a science-based framework for strategic sustainable development. We call for more action-based research to uncover the complex nature of sustainable supply chain management, as there are unique challenges and dynamic relationships in every supply chain.
\end{abstract}

Keywords: case study; organizational learning; strategic sustainable development; sustainable supply chain management; sustainability

\section{Introduction}

The global business community is increasingly recognizing the need to integrate sustainability thinking into their business activities and benefits. A "license to operate" increasingly requires legitimacy from the public to show responsibility and societal engagement [1]. Several authors have also pointed to direct self-benefits for businesses proactively pursuing sustainability, innovation, and market opportunities [2-4]. With an increase in globalization and the complexity of supplier networks, there is an increased business interest in managing these networks' sustainability performance. However, the ability to do so is still weak [1]. Prior research also shows discrepancies between corporate rhetoric in policy and mission statements on the one hand and firms' actions on the other [1,5-7].

Sustainable supply chain management (SSCM) has been defined as integrating systems thinking, strategy, and action into supply chain management, including financial, ecological, and social performance [8]. While SSCM research increases maturity [9,10], reviews in the field point to gaps in the literature. These gaps are due to a lack of researchers providing a holistic perspective on sustainability, resulting in more substantial attention to ecological and economic issues than social issues (e.g., [11-14]. This includes focusing on how unsustainable supply chain practices can become less unsustainable rather than genuinely sustainable [7]. In this study, we generally use the term supply chain while recognizing 
that the supplier system consists of a complex network. Moreover, reviews point to an emphasis on the "what" of SSCM rather than on the "how" [7], and, as a result, there is a lack of procedural support for how to implement SSCM (e.g., [10,15]).

Implementing SSCM and contributing to truly sustainable business management, in general, is a transformative task. Such a change in thinking is discussed in organizational learning $[16,17]$. Organizational learning has been defined as "the mutual learning of an organization and the individuals in it" [18] and "a dynamic process of creation, acquisition, and integration of knowledge aimed at developing the resources and capabilities that allow the organization to achieve better performance" [19]. All development involves learning [20] and, thus, learning is vital for any organization's sustainability performance $[16,21,22]$. From a societal perspective, where organizational learning and change are described as critical components for long-term success on the path toward sustainability [23], its continuity is claimed to be vital to achieving sustainable development [17]. Thus, it is logical that Oelze et al. [24] found that organizational learning is a crucial success factor for implementing SSCM. However, these authors also called for more empirical support of this factor's importance from established systematic processes at the organizational level.

This study explores how to implement SSCM as part of a strategic organizational transformation process. We find that the transformational process increases sustainability, integration, and overall performance benefits to stakeholders. In addition, we attempt to fill a gap in the SSCM literature regarding a lack of a holistic perspective on sustainability and a lack of procedural support for implementing more sustainable management practices.

We start by describing the foundations of the applied sustainability framework used by global organizations for decades. We then outline the resulting case-based research and design of support methodology. Next, we review empirical insights from the case study, followed by the resulting implementation process to support strategic SSCM. Lastly, we conclude and discuss our findings and propose opportunities for future research.

\section{A Holistic and Practical Approach to Sustainability}

According to the identified need for a holistic and practical approach to SSCM, we needed to inform this study and develop a proposed implementation process model using a holistic methodology for strategic sustainability. This approach has proven useful as we utilized the framework for strategic sustainable development (FSSD) [4]. The significant features of this framework are described below.

For planning and acting in complex systems, especially when desiring systemic changes, backcasting, i.e., to start with a vision in mind and ask "what do we need to do today and subsequently to get there?", has been argued to be a preferred approach [25-27]. Furthermore, backcasting from visions framed by a principled definition of sustainability, which is an essential component of the FSSD, has been argued to have advantages over backcasting from detailed visions without such framing [4]. For example, the first suggests a way to assess whether proposed visions are sustainable or not, and common basic principles facilitate transferability of learnings from one planning endeavor to another. The FSSD is also built from the understanding that it is easier for many people to agree on a principled description of a sustainable future. Using the framework means keeping details of the visions flexible and open to change as the plan unfolds and is adjusted. This approach is more manageable than getting many people to agree upfront on a specific and detailed vision. According to Broman and Robèrt [4], locking in the details early in a process is unwise when considering the technological evolution that will happen during the transition and that cannot be predicted in detail.

To be useful for backcasting, planning, and redesign toward a more sustainable future, as well as for assessment, the framing principles should, according to the authors, be necessary and sufficient for sustainability, as well as general enough to be applicable in all contexts, concreate enough to guide innovation, and nonoverlapping enough to facilitate 
understanding and development of indicators. The FSSD includes a principled definition of sustainability that has been developed with these criteria in mind. It reads as follows:

"In a sustainable society, nature is not subject to systematically increasing ...

1. ... concentrations of substances extracted from the Earth's crust (e.g., fossil carbon or metals).

2. ... concentrations of substances produced by society (e.g., NOx or per/polyfluoroalkyl substances (PFASs)).

3. ... degradation by physical means (e.g., over-harvesting of forests or over-fishing). and people are not subject to structural obstacles to ...

$4 \quad \ldots$ health (e.g., by dangerous working conditions or insufficient rest from work).

$5 \quad$... influence (e.g., by suppressions of free speech or neglect of opinions).

$6 \quad$... competence (e.g., by obstacles to education or personal development).

$7 \quad$... impartiality (e.g., by discrimination or unfair selection to job positions).

8 ... meaning-making (e.g., by suppression of cultural expression or obstacles to co-creation of purposeful conditions)."

Here, structural obstacles are social constructions-political, economic, or culturalwhich are firmly established in society and upheld by those with power (political, economic, or other forms), and which are, due to a variety of interdependencies, challenging to overcome or avoid for the people exposed to them [28].

These principles are used as boundary conditions for visions; anything within these boundaries is sustainable, whereas anything outside them is not (see Figure 1).

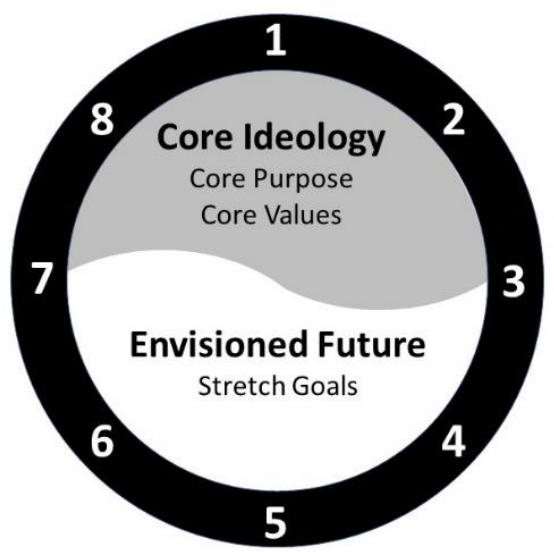

Figure 1. Vision with sustainability principles as boundary conditions.

A sustainability framework should include procedural support for the cocreation of visions and strategic plans for practical application. The FSSD provides this with the ABCD procedure. This planning procedure is precisely aligned to support a strategic assessment of sustainability opportunities, baseline information, the development of creative solutions, and the prioritization of actions. This procedure has some similarities with Deming's Plan, Do, Check, Act at a process level. Other similarities include using the ABCD procedure to unpack the ecologically dominant logic presented by Montabon et al. [12]. The FSSD and $A B C D$ planning procedure operationalizes environmental, social, and economic capabilities mentioned in prior studies. The ABCD approach is more comprehensive than TQM, with extensions to total quality environmental management (TQEM), and it helps to turn theoretically dominant logic into practice.

Step A: This step includes learning about the sustainability challenge and related opportunities for the organizational system taking part and about the FSSD in general, including this procedure. Participants in the planning then cocreate an initial vision or visions framed by the above sustainability principles. Different stakeholders might want to 
create different preliminary visions. However, all are framed by the same basic principles for sustainability to ensure that they are compatible and sustainable.

Step B: This step includes assessing the current situation for the organizational system in relation to the vision(s). This includes identifying current challenges and current strengths and capabilities of the organizational system that are potentially useful for realizing the transition toward the vision(s). This assessment might require further learning about and mapping the organizations' dependencies on the ecological and social systems and the stakeholder networks.

Step C: This step includes creative co-development of possible actions to address identified challenges and to capture identified opportunities, i.e., to generate possible actions to overcome the gap between the current situation and the aspired vision(s).

Step D: This step includes prioritization of the identified possible actions into a strategic plan. Basic strategic guidelines imply that early actions should be (1) flexible platforms for future actions that, taken together, are likely to support society's transition toward sustainability and take the organization(s) to the sustainability-framed vision(s) while striking a balance between (2) the pace of progress toward the vision and (3) return on investment.

The FSSD also includes specific support for understanding the self-benefit for individual organizations to act proactively to be more sustainable and support the categorization and clarification of inter-relationships of data and phenomena.

These features have been in practice in many examples and contexts over the last two decades (e.g., see [4]). Therefore, the FSSD can be helpful as a guiding sustainability framework for the development of implementation support for SSCM. It should facilitate, e.g., combined attention to firms' ecological and social aspects and strategically more optimal joint handling of tradeoffs among stakeholders. There are many other conceptual models and frameworks regarding sustainability and supply chains (e.g., [29-32]. We do not see those as competing models or frameworks but believe that their combined use with the FSSD can be mutually beneficial. However, the purpose of this study is not to review and map the whole field from a strategic sustainability perspective and point to all possible synergies. Instead, as the FSSD has been overlooked by some and possibly underutilized in supply chain management research, we introduce it as a foundation for a proposed SSCM implementation process model. Through this approach to our field-based research, we attempt to illustrate how an example SSCM implementation model can provide new insights into this field of research and practice.

\section{Methodology}

\subsection{Overall Research Design}

This study is iterative and inductive, combining results from a single-case study and applying an existing framework with a literature review to outline a process model. We used the following design criteria for this study: (1) the research study and its activities should be built on engagement between scholars and practitioners so that a double hurdle of research quality and business relevance can be overcome [33,34]; (2) a systems perspective should be used, to ensure a complete sustainability framing and facilitate strategic sustainable development $[4,35]$; (3) theories of organizational learning should be considered, to facilitate change $[16,17,21,36]$.

We applied these criteria in a two-step research process (see Figure 2). First, we used a case study to explore how the FSSD can support change management to integrate sustainability into a company's core business Sroufe, [37]. This case is an example of integrated management, i.e., "the process of including environmental, social, and governance (ESG) performance in close coordination between business processes, functions, groups, organizations, and systems" [37]. In particular, we wanted to see how the FSSD and integrated management support the implementation of strategic SSCM. Then, as a second step, we developed an implementation process model for strategic SSCM by synthesizing empirical insights from SSCM and organizational learning literature and our work in the field. 


\section{Framework for Strategic Sustainable Development (FSSD)}
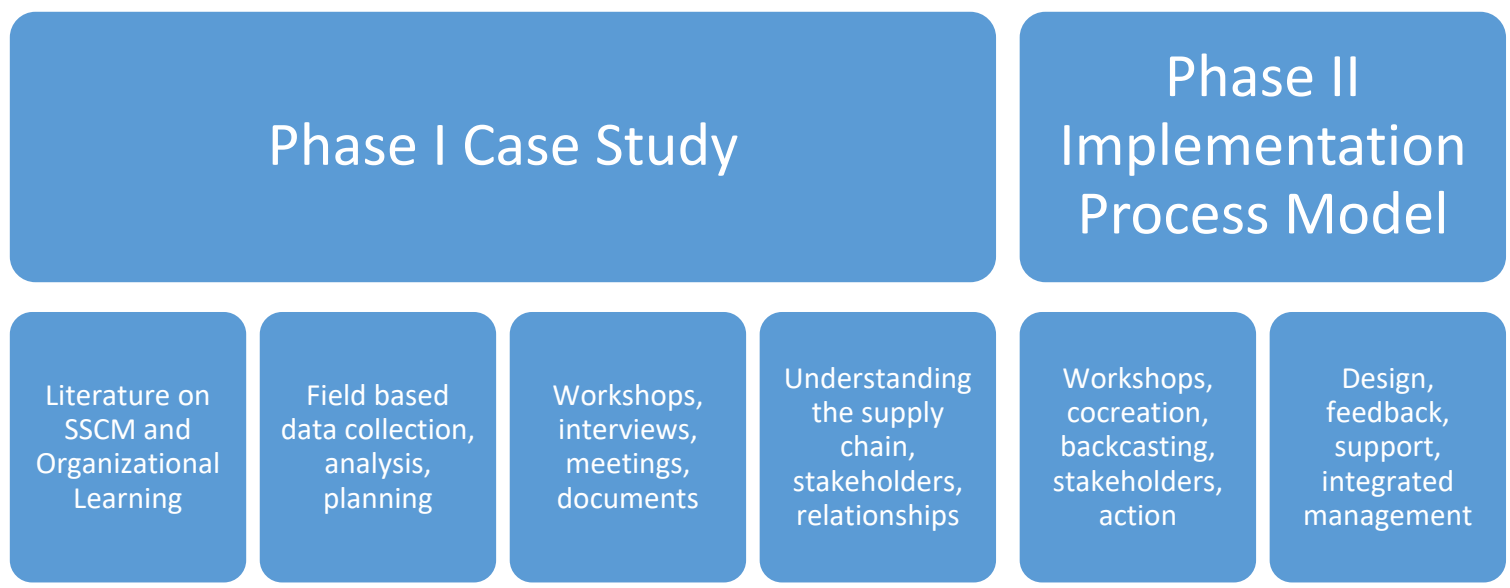

Figure 2. Field study phases and interactions.

This methodology is based on qualitative insight and research as an iterative process [38-40], whereby knowledge can be seen as a product of constant iteration between theory and practice toward understanding generative mechanisms [41]. Thus, a qualitative approach was appropriate for this study as our research focus relates to describing and unfolding a series of actions over time in a given organization while understanding the change management process to learn from it [42]. While the study was an iterative research process, its development took part in two main steps further described below.

\subsection{The Case Study}

The case study aimed to understand, in-depth, the dynamics present within a single setting, in which qualitative information collection and analysis helped to develop a mutual understanding of what emerging concepts are important [38], particularly what is needed to make progress toward sustainability as defined in this study. A single company fits the research needs as we wanted to focus our examination on one industry and one proactive firm within that industry. For this study, we wanted to work with a company attempting to create change internally and within its supply chain through a new strategic sustainability initiative while providing the potential for generalizable conclusions [43].

The case company chosen expressed an ambition to increase its competitiveness by working more seriously with its overall sustainability performance. The company was developing and providing long-life fluorescent light sources and light solutions. The company developed and had its production of fluorescent light sources. Their product portfolio also included long-life light-emitting diodes (LEDs). The company was mainly a final assembler of halogen light sources and controls, sensors, and fixtures. The company wanted to shift its business model from mainly selling physical products to mainly selling service-oriented lighting solutions. In addition to the physical products, this would include lighting studies, installation, performance guaranty, maintenance service, and a financial arrangement, which could involve, e.g., the handling of $\mathrm{CO}_{2}$ certificates.

Our objective was not to prove or disprove the company's achievement of this goal. Instead, we wanted to find new insight into how a company is changing its strategic focus and its supply chain to include sustainability thinking through the application of the FSSD. The company has worked with scholars and consultants for more than 10 years. 
This, combined with an engaged approach to research, created a level of trust needed for vital information to be shared [34]. The research group involved three partners: academic scholars, including one of the authors of this paper, a sustainability consultancy applying the FSSD, and the case company.

Co-planning of interactions between the scholars and the consultancy partner provided a foundation for learning. These interactions included full-day workshops with the management board of the case company, as well as eight in-depth interviews with the CEO, the General Manager Southern Europe, the Vice President Product Development, the Supply Chain Manager, the Sustainability Manager, and the Business Controller Nordic and UK. This spanned 2 years. The scholars also had a separate meeting with the sustainability manager and the supply chain manager on one occasion and with the $\mathrm{CEO}$ on other occasions. In the full-day workshops, the consultancy firm acted as facilitator, provided FSSD-based knowledge, and stimulated learning within and between the workshops by supported homework.

In these settings, the scholars acted in the observer-as-participant role while closely following all communication between the case company's management team and the advisors from the consultancy. The management team was informed about academic scholars' presence and the purpose of the study, but the company was entirely responsible for all business decisions. Information gathering was developed from direct observation during the all-day workshops and from follow-up communication with participants. Information was also collected from reviewing company documents, either provided by the management team or interviewees or found in the public domain. The former included a supplier policy, a supplier self-assessment questionnaire, and a supplier audit questionnaire, drafts of new business models and the supply chain, and a market overview of the lighting sector done on behalf of the case company by an external actor. The public documents included annual sustainability reports. Information was also retrieved by studying documents developed successively by the consultancy and reviewing the science related to emerging sustainability issues, such as issues related to LED technology and phosphorus use in lighting.

\subsection{Developing Support}

This phase included the synthesis of insights from the case study and literature on organizational learning and SSCM. These insights then guided the structural logic of the FSSD. Feedback regarding the suggested SSCM implementation process model was obtained and discussed during two half-day workshops at the Blekinge Institute of Technology (BTH) while exploring the support's situational usability. Situational usability is the quality-in-use of a system in a specified situation with its users, tasks, and the broader context of use [44]. These workshop participants included academic scholars, the sustainability manager and the supply chain manager of the case company, and sustainability managers of four other partner organizations of BTH. The implementation process model design included continuously revisiting the literature on SSCM and organizational learning before and after the workshops.

\section{Findings and Discussion}

\subsection{Outcome 1-Results of the Case Study, Top Management Level}

\subsubsection{Understanding the Sustainability Challenge and Cocreating a Vision}

A vision and long-term objectives were cocreated through close interaction between the sustainability consultants and the case company's management team. This cocreation was accomplished with a series of three workshops, including all functional managers of the company and communication in between workshops. The scholars participated in the second and third workshops. Initially, the participants discussed sustainability challenges and the need for taking a systems perspective; the company participants learned about the FSSD. This participation enabled a shared understanding of challenges and opportunities and provided a shared language for future work. When co-developing the vision, the 
sustainability principles of the FSSD served as a frame. The cocreation process generated top management commitment to the new vision, to "become the leading global partner for sustainable lighting solutions to professional customers". The core purpose (mission) and core values of the company were agreed to be the following: "we develop and supply lighting solutions for professional customers, enabling them to reduce cost and become sustainable" by being "dedicated, agile, and innovative". The process also included the cocreation of "pillars for success" to guide further steps. These pillars included innovations for tomorrow, smart solutions for users and society, our people and partners for change, and responsible business operations. For each of these, long-term objectives were co-developed, among which the scholars identified the following as relevant for SSCM:

(i) Sustainable raw material sourcing,

(ii) Optimized logistics and sustainable transports,

(iii) A positive impact on the local communities,

(iv) No scarce materials or substances that risk increasing in concentration in nature,

(v) No health and safety risks,

(vi) Sharing and developing competence in sustainability,

(vii) Developing partnerships with customers, suppliers, communities, nongovernmental organizations, universities, and governments (developed later, see below).

Each objective was discussed regarding its potential to contribute to the new vision and explicitly concerning the sustainability principles of the FSSD.

\subsubsection{Assessing the Gap between Current Practices and the Vision}

To help understand product and supply chain sustainability performance, the consultancy firm used an FSSD-based tool called strategic life cycle assessment (SLCA) in two participatory workshops. The tool provides a strategic look at the full scope of social and ecological sustainability throughout product life cycles. While the tool's focus is on the current situation, it also captures ongoing activities and capabilities that can impact the current situation. It results in a matrix that allows the company to see the estimated significant impacts of current products. Applying this tool as part of the workshops creates awareness and competence in sustainability among the participants. After each workshop, participants did homework, which indirectly involved a broader group of employees, i.e., product developers and purchasers. The progress of the homework was reviewed by the consultants through e-mail communication and monitored by scholars.

The tool's application involved two of the company's products and their supply chains: a standard fluorescent light tube and a long-life light tube (four times longer life). The results uncovered a general lack of knowledge regarding raw material extraction, raw material processing, production processes at suppliers, and transport phases. The SLCA identified specific hotspots, including (i) leakage of mercury to nature, as well as health risks in the handling of mercury, (ii) $\mathrm{CO}_{2}, \mathrm{NOx}$, and other emissions from energy use, and (iii) the use of phosphorus in the light sources (discussed mainly from a perspective of resource scarcity). Since neither the transportation nor LED light sources were assessed in the workshop settings, additional interviews were necessary with the supply chain manager and the LED product responsible for gaining further information. The interviews revealed a lack of environmental requirements on transportation partners in general and that the logistical efficiency, from providers to customers, was low. Interestingly, they found that the product and process knowledge regarding the LED chip was low; the supply chain manager stated the following: "Knowledge about this is up the chain. We do not have it."

It was clear there was a significant lack of upstream information. They lacked visibility beyond their first-tier suppliers, and this included the LED supply chain. These blind spots were found and agreed upon to include both hidden risks and opportunities from a strategic sustainability perspective. This gap was considered critically important, and the need for a more thorough supplier network mapping and the suppliers' earlier involvement was agreed upon. Interviews with the CEO and business controller showed that the company 
expected the share of LED to increase in its product portfolio. In parallel, and with the insight from these interviews, a literature review conducted by the scholars and shared with participants helped increase company learning on LED manufacturing and end-of-life issues. For example, it was found that LED chips may contain arsenic, gallium, indium, and antimony $[45,46]$.

Moreover, LED chips are assembled into a usable pin-type device by applying wires, solders, glues, adhesives, and heat sinks, and these ancillaries may contain copper, gold, nickel, and lead [47]. The rapid growth in the LED industry with increasing LED-related waste streams has potential implications related to resource availability, human health, and ecosystems [47-49]. While LED facilitates a phaseout of mercury (used in fluorescent light sources), it is essential to be aware of these other metals' sustainability implications and handle them to prevent new problems.

The discussion focused on the availability and priority of phosphorus (which is part of the lighting powder of fluorescent light sources and the coating of the full-spectrum LED light sources). This discussion embraced the fact that phosphorus is an essential substance for life itself, and whether it is viable to use it in light sources. It was concluded that this depends on overall availability, amounts being used, and possibilities for recycling. The availability of any substance is a dynamic and complex concept. It was taken into consideration that at least some researchers estimate that the current global reserves of easily accessible phosphorus will be depleted within the next 50-100 years. This depletion is based on current consumption rates, and it was noted that phosphorus scarcity is one of the crucial issues for global food security [50,51]. Effective recycling policies are, therefore, crucial [52]. It was concluded that the current dependency on phosphorus in light sources and some rare earth metals implies an economic risk for the company, and they have already experienced significant price spikes in the marketplace [53].

The above insights were also shared with the product development team of the case company.

\subsubsection{Realizing Self-Benefits}

From the interviews, it also became evident that the consultants' learning activities made the management team more aware of the potential benefits of being proactive for sustainability, including increased competitiveness from taking a systems perspective on their products and services. These outcomes aligned with a previous study also supporting the benefits of providing light as a service [54]. The study compared a standard fluorescent light tube and a long-life light tube, and the business model's ordinary product sales and "offering light as a service". Offering light as a service with long-life light tubes was found to be (i) economically preferable for the customer due to decreased life-cycle costs and avoidance of high initial investments, (ii) economically preferable for the producer since parts of the total cost savings from the use phase can be captured by the producer, and (iii) preferable from a sustainability perspective because of increased energy efficiency, decreased flows of material, and increased possibilities for closed-loop systems.

\subsubsection{Stakeholder Analysis}

To deepen their understanding of current dependencies, the case company decided to conduct a stakeholder analysis at the management level. This was done in collaboration with the sustainability consultants and scholars. It also resulted in a deeper understanding of what other stakeholders would be essential to achieve the vision.

For example, it was realized that stakeholders were not only economically aligned with the supply chain, but also had interests in the company's ecological and social performance. This insight was an essential outcome of the interactive research process. Due to this, a new key objective was developed, namely, to "develop partnerships with customers, suppliers, communities, nongovernmental organizations, universities, and governments". 


\subsubsection{Case Company Conclusions}

Based on the above and e-mail dialogues between the CEO and the scholars, the company made the following conclusions:

1. Utilizing long-life products within a service offer could add benefits for customers and the company while contributing to societal sustainable development. However, from a full sustainability perspective, there were two main aspects to address: mercury and phosphorus use. It was expected to remain challenging to keep the mercury used in fluorescent light sources in fully closed loops. A successive transition to (mercuryfree) LED light sources was identified as a strategic action. This was also based on the fact that LED light sources are significantly more energy-efficient and provide more opportunities related to advanced control systems. Thus, LED technology was concluded to support the company's ability to sell high-quality lighting (and other functions) as a service.

2. LEDs have other sustainability challenges. However, with the significant gain in energy efficiency and possibilities for added functionality, and the potential to mitigate the LED-related sustainability challenges, LED technology still stood out as a suitable flexible platform toward fully sustainable lighting solutions.

3. To achieve the vision of truly sustainable lighting solutions, the company needed to consider the full supply chain and its stakeholders' achievements supporting all sustainability principles. It was realized that the case company did not understand its full supply chains, and even less so the new supply chain for LEDs. Therefore, further mapping of the supply chain and its stakeholders became a key priority to achieve the vision. The company also realized a need to improve relationships and trust with a broader group of suppliers. It was also noted that this would be challenging with a partly new supply base when shifting to selling more LEDs and lighting as a service.

4. Lastly, the case company concluded that, to achieve change toward SSCM, the company also needs external strategic collaboration with, e.g., new suppliers, service firms, sustainability experts, and auditing firms.

\subsection{Outcome 2-Results of the Case Study, Supply Chain Management Level \\ 4.2.1. Understanding Current Supply Chains}

It became evident that a better understanding of the entire supply chain was needed. Only the first-tier suppliers were known for some materials. To work toward the new vision, the $\mathrm{CEO}$ and the supply chain manager realized the need to comprehensively map the supply chains and other key stakeholders to understand their sustainable supply chain better. Some of the purchasers were also involved in this activity. It became clear that their supply chain was an interlinked network and resulted in a clear picture of this overall supply network and some stakeholders linked to it (see Figure 3). This figure illustrates the supply network as stakeholders, flows of products, and circular raw materials. It is not intended to identify the roles, responsibilities, or explicit materials of the suppliers. The suppliers comprised ordinary material or component suppliers and subcontractors, i.e., companies coproducing finished products. Some of this was for local markets in Asia. In this location, the subcontractors managed their quality control and logistics and, thus, were in charge of any potential SSCM.

The next step was to understand the sustainability performance and vision's critical capacities among its main suppliers. Strategic suppliers were defined as suppliers that the case company was dependent upon, either for coproduction to achieve the volumes needed or for supplier scarcity reasons. However, with the new insights and vision, the case company realized they need to engage with other suppliers and that "strategic" suppliers should include suppliers with high sustainability performance. 


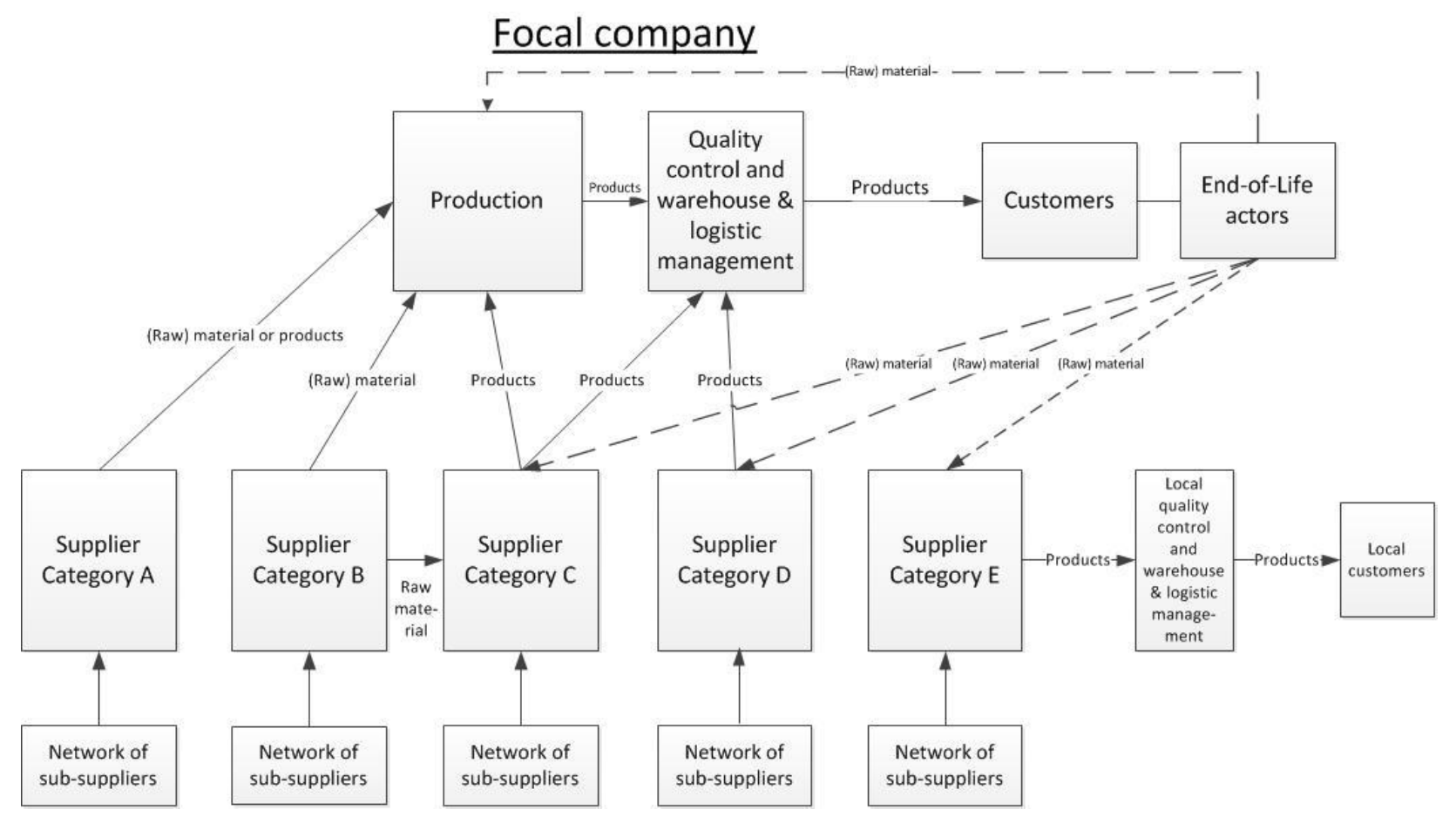

Figure 3. Supplier network.

At this point, the case company decided, in line with the stakeholder analysis, to bring in another consultancy firm with a local presence in the suppliers' regions. For this, the first self-assessment tool was developed with the new consultants. To help support future supply chain management efforts and the purpose of the audits to be performed by the local consultancy firm, the scholars developed a prototype for strategically assessing suppliers from a strategic sustainability perspective. It was reviewed and discussed with the sustainability and supply chain manager. This discussion provided the basis for further development by the scholars (see excerpts from the prototype in Section 4.3.4). The selfassessment tool was rolled out to 10 appointed suppliers. The case company conducted a first on-site visit at five suppliers, including applying to tool to parts of the prototype.

\subsubsection{Developing Relationships with Supply Chains and Stakeholders}

In another meeting between the scholars and the sustainability and supply chain manager, it was deemed necessary to achieve the vision and long-term objectives to assess the main suppliers from a sustainability perspective and take action toward developing a closer relationship. The list of strategic suppliers at this point was expanded to include LED and full solution suppliers. The company already had strong relationships with some of its long-life fluorescent lamp suppliers, all linked to specific individuals at the case company and the respective supplier. These relationships were highly valued and successively invested in overtime. However, this was not the case with the LED and full solution suppliers. They were all relatively new as suppliers, with no relationship developed between individuals, and some were identified as having high risks for negative sustainability impacts. Beyond developing relationships, it was also agreed that there was a need for a shared understanding of sustainability along the supply chain. While the plan was not taken to its final implementation during the case study, some first steps were agreed upon: (i) to start sustainability dialogues with the management team of key suppliers, and (ii) to identify key individuals at the case company with some already established relationships with all identified strategic suppliers.

For (i), the latter consultancy firm, with both local presence and language competence, was involved. An incentive for utilizing this consultancy firm was that the case company at this time had no interaction or engagement with the communities where the suppliers were 
located, and the sustainability and supply chain manager recognized the local presence of this consultancy firm as a flexible platform for building future engagements with the local communities. The sustainability and supply chain manager appointed individuals from the purchasing department in the case company to take part in the relationship building.

A necessary future step in the action plan toward SSCM included cultivating relationships with others in the value chain network. During the learning process, it was found that waste streams can increase with new technologies such as LED and that this waste needs to be strategically dealt with. The sustainability and supply chain manager stated the following: "Maybe, in the future, we ought to be much more careful when choosing our customers so that we will be able to say we take full responsibility for our products." Providing lighting as a service was recognized as having the potential for cultivating long-term and closer relationships with customers.

\subsubsection{Post-Study Insights}

In discussions among the authors after the case study, we reached some generalizable, high-level insights; some examples are listed below.

1. The cocreation of an agreed-upon vision and mission statement among all functional managers of a company is vital when pushing for significant change. The result from such a process can serve both as a catalyst for change and as a guide for decision making and forms a foundation for, e.g., more strategic handling of tradeoffs. The result is that the process helps create a shared understanding of sustainability throughout the organization. In addition, it creates a sense of ownership of the agenda for change. This kind of engagement also creates shared responsibility for the results and implementation. To realize a sustainability agenda in an organization, which involves significant complexity and requires cross-disciplinary and cross-functional collaboration, the setup and coordination of internal cross-functional teams and defining roles and responsibilities are also vital. Of particular relevance to SSCM is establishing closer collaboration between the supply chain management function and the product development function.

2. We need informed leadership if we are going to achieve and manage sustainable supply chains. In line with item 1, this leadership includes building a learning organization around a shared understanding of sustainability across functional units and organizations in the supply chain.

3. Long-term personal relationships built on trust are essential to sharing information, achieving shared understanding, and buy-in among suppliers. Thus, innovative companies with a changing supply base have an additional challenge as relationships will need to be built continuously with new suppliers.

\subsection{Outcome 3-Developing Support, an Implementation Process Model for SSCM}

In what follows, we present a process model for SSCM implementation. This implementation process is a direct outcome of the case study engagement and cocreated with management. This implementation builds on a synthesis of empirical insights from the described case study and a review of the literature on organizational learning and SSCM. Although the process has an overall flow, iterations between the steps and readiness to address more than one step can be necessary for decision making within dynamic systems. The vision was cocreated by stakeholders and was developed in conjunction with two-way information flows from this process. This information flow is represented with two-way arrows with the vision at the center of activities. As a result of stakeholders' visioning process and knowledge, a select few categories are addressed in each step as the categories are based on the outcomes of the engagement process. The overall flow is visualized in Figure 4. Attention is given to "what" to do, "who" should be involved, and "expected outcomes" as research propositions for future research in the subsections below. 


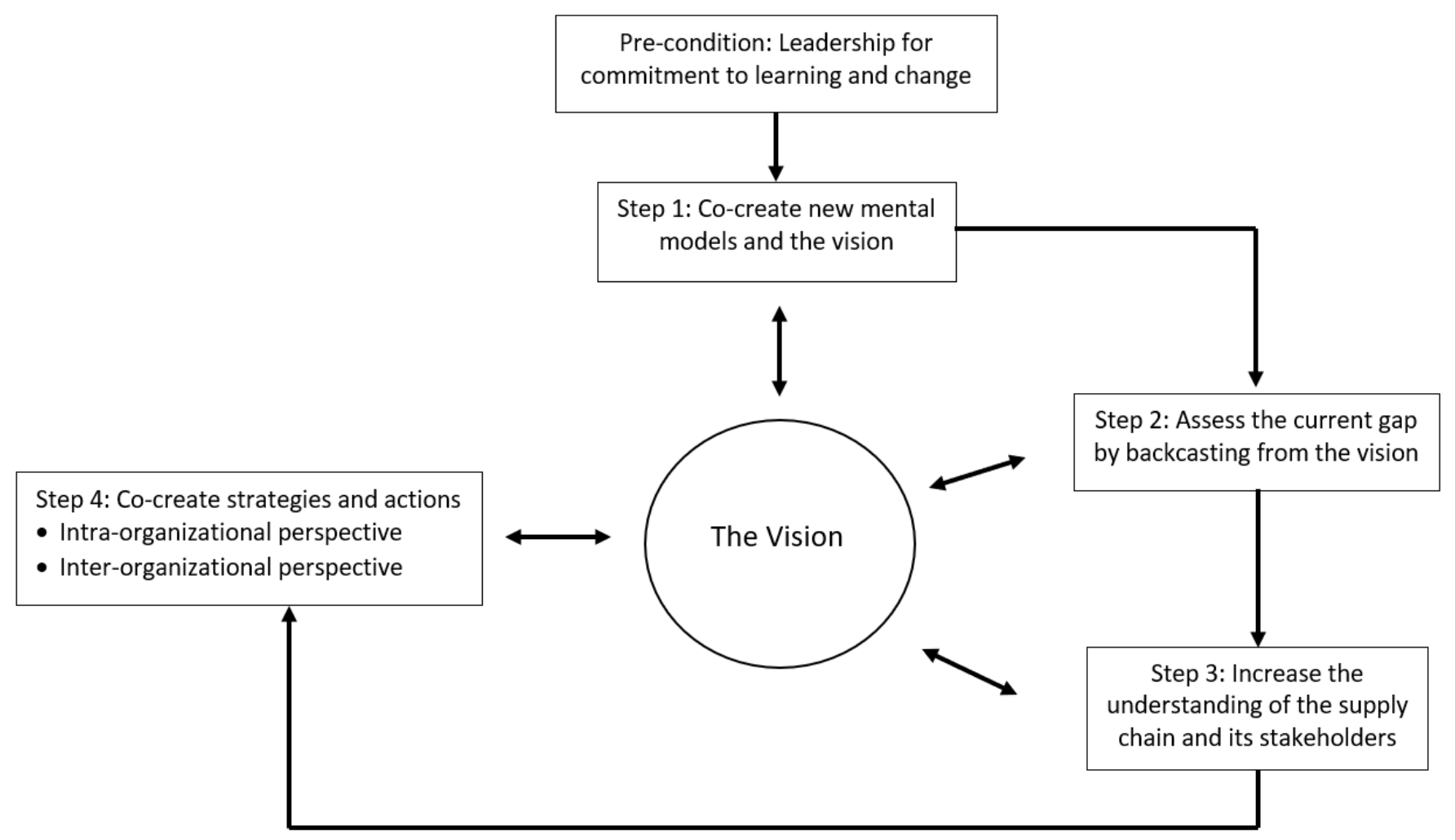

Figure 4. An overview of the implementation process model for SSCM.

\subsubsection{Precondition-Leadership for Commitment to Learning and Change}

An essential first step is for top management to understand the current global sustainability challenge. The organization's success depends on "creating wellbeing within the larger system they operate" [55]. Leadership's ability to see the more extensive system and commit to learning and change provides the start for all sustainability work (e.g., [21,56,57]. This is particularly important in the context of SSCM [2,24,58]. Therefore, leadership and commitment are crucial antecedents to creating new mental models needed to guide further actions [59-61]. Observations in the case study confirm these assertions.

\subsubsection{Step 1-Cocreating New Mental Models and a Vision}

What: Rosner [62] stated that "existing mental models-of managers, politicians, consumers, of everybody-influence to a large part the decisions made and, therefore, these models can be part of the problem itself. The 'unlearning' of old models and the provision of new ones are part of the solution." Mental models have been referred to as deeply held assumptions through which we see and interpret the world and from that act $[59,63]$. Long-held organizational foundations and mental models must be unlearned to make successful SSCM implementation and large-scale impact possible $[62,64,65]$. New knowledge is necessary for new mental models to be created $[62,66]$. When this new knowledge is found, we propose that an understanding of "external" sustainability is necessary for "unlearning" old models and for learning about new opportunities [24]. Knowledge can come from academia and sustainability experts in consultancies. There also needs to be a culture in which individuals can ask tough and intelligent questions while searching for the answers $[17,67]$. We propose that learning should happen in cross-functional settings. Mohammed and Dumville [68] supported this approach to learning, stating that group learning across functions is vital when developing new mental models. New mental models can emerge when old and new assumptions are exposed and scrutinized regarding consistency and accuracy $[59,62,69]$. 
This step involves the cocreation of a shared vision needed to provide all employees with direction and goals $[4,70]$. Therefore, such as vision should include, in addition to a vision statement, core purpose, core values, and stretch goals for the future [71] (see Figure 1). As was evident in the case study, the vision and the process of its creation are essential. The purpose is (i) to create a guiding, inspiring vision, and (ii) to use this creative process for building engagement and commitment across groups of actors [63]. According to, e.g., Senge [72], a shared vision has the power to foster genuine commitment and a sense of the long-term while encouraging experimentation and innovation. The creation of the company vision should, therefore, also be a cocreation, with cross-functional activity. Willard [3] says that this process is "about using the appropriate visioning process to arouse passion and create buy-in. People have a strong desire to make a difference and leave a legacy. Collective energy, inspiration, and pride from aligned visions/aspirations will provide the power grid for new change effort ahead." While core values and organizational objectives will be context-dependent, our proposed model includes a vision framed by science-based, generalizable sustainability principles (see Figure 1). As asked by Broman and Robèrt [4], "why aspire to a future that cannot be?" Sustainability principles are used as boundary conditions for what is to be achieved imply flexibility regarding details while assuring that the vision is sustainable. This type of constraint is known to stimulate creative solutions [73].

In line with Willard [3], we argue that it is beneficial to establish a senior-level sustainability team in large and medium firms, including the supply chain manager. This team should have the authority to support and legitimize the sustainability transformation, be accountable for it, integrate the needed learning mechanisms for continuous organizational learning, and ensure that progress status is an agenda item in regular senior meetings.

To realize the benefits of becoming a sustainable organization, leaders will need to work with supply chains toward sustainable outcomes. In the case study, we saw a shift in the main focus from short-term costs and profits to finding and creating long-term value in the more extensive system. These findings align with what Senge [59] has called for, i.e., combining collaboration and organizational learning.

Who: Top managers, functional managers, and sustainability experts.

Expected outcome and research propositions: Cocreating models and a new vision enable change as (1) managers see the company and its supply chain as a subsystem of the global ecological, social, and economic systems with its sustainability challenge and related opportunities, (2) managers have a "mental" commitment to change and continuously learn regarding how to contribute to sustainable development and long-term business success, and (3) managers have a shared understanding of, and commitment to, a vision, including mission and core values.

\subsubsection{Step 2-Assess the Current Overall Gap by Backcasting from the Vision}

What: Next, the organization needs to understand the overall gap between where it is and the vision. In this step, the management team and the functional managers, such as the sustainability manager, the supply chain manager, and purchasing manager, assess the current situation of the organization and its value network concerning the vision, especially on a high level in relation to the framing sustainability principles.

Who: Top managers, functional managers, and sustainability experts.

Expected outcome and research proposition: Backcasting from the vision closes gaps, thus enabling change management. This step provides an understanding of the most significant challenges and strengths of the organization, including the need for investing in SSCM.

\subsubsection{Step 3-Increase the Understanding of the Supply Chain and Its Stakeholders}

What: Once a cross-functional understanding of the most significant challenges and strengths is reached, a more in-depth understanding of the supply chain is a challenging next step [1]. We realize that the need for transparency and information disclosure has expanded beyond corporate boundaries into supply chains [74]. Many companies with 
global supply chains, including the case company, struggle with this (e.g., [31]). Achieving a sustainable supply chain is a long-term process that includes iterations between all steps of the process we propose in this study. An early step should be an overall sustainability assessment of the supply chain to capture the current level of transparency. For this purpose, a Supply Chain Assessment Tool was prototyped. This tool's purpose is to identify risks (violations of sustainability principles) and opportunities by supporting backcasting from the vision. While the prototype is too extensive to present in this study, we believe it adds value to show some excerpts given in Table 1a,b.

Table 1. (a) Excerpt 1 from The Supply Chain Sustainability Assessment tool regarding Sustainability Principle \#2. (b) Excerpt 2 from The Supply Chain Sustainability Assessment tool regarding Sustainability Principle \#5.

\begin{tabular}{|c|c|c|c|c|c|}
\hline \multicolumn{6}{|c|}{ (a) Excerpt 1 from the Supply Chain Sustainability Assessment Tool Regarding Sustainability Principle \#2 } \\
\hline \multicolumn{2}{|c|}{ Sustainability Principle \#2 } & \multicolumn{4}{|c|}{$\begin{array}{c}\text { Targets/Action Plan Related to Risks of Systematically Increasing Concentrations } \\
\text { in Nature Substances Produced by Society }\end{array}$} \\
\hline \multicolumn{2}{|c|}{$\begin{array}{l}\text { Contributions to a systematic increase in } \\
\text { nature from: }\end{array}$} & \multicolumn{4}{|c|}{ Chemicals } \\
\hline \multicolumn{2}{|c|}{ Desired } & \multicolumn{4}{|c|}{$\begin{array}{l}\text { Co-developed targets and action plans for transparency and phase out chemicals that } \\
\text { are toxic and/or persistent and/or bio-accumulative and risk increasing systematically } \\
\text { in their concentrations in nature. }\end{array}$} \\
\hline \multicolumn{2}{|c|}{ Overarching questions } & \multicolumn{4}{|c|}{$\begin{array}{l}\text { Examples of questions for understanding the suppliers' overall capacity for making } \\
\text { progress. Has the focal company taken actions for the co-development of targets and } \\
\text { action plans to: } \\
\text { 1. Achieve full transparency of what chemicals used in products or production? } \\
\text { 2. Achieve knowledge on what chemicals are ranked as a Substance of Very High } \\
\text { Concern (SVHC) within REACH and why and made a comparison? } \\
\text { 3. Reduce and/or substitute SVHC chemicals or others that risk increasing } \\
\text { systematically in concentration in nature? }\end{array}$} \\
\hline \multicolumn{6}{|c|}{ (b) Excerpt 2 from The Supply Chain Sustainability Assessment Tool Regarding Sustainability Principle \#5 } \\
\hline \multirow[t]{2}{*}{$\begin{array}{l}\text { Sustainability } \\
\text { Principle \# } 5\end{array}$} & \multirow[t]{2}{*}{$\begin{array}{c}\text { Overarching } \\
\text { Question }\end{array}$} & Employees or Wo & $\begin{array}{l}\text { ers in the Supply } \\
\text { n }\end{array}$ & \multicolumn{2}{|c|}{ Communities } \\
\hline & & General category & Specific example & General category & Specific example \\
\hline \multirow{2}{*}{$\begin{array}{l}\text { Contribution to } \\
\text { structural obstacles } \\
\text { to influence }\end{array}$} & \multirow{2}{*}{$\begin{array}{l}\text { What social } \\
\text { conditions occur } \\
\text { that systematically } \\
\text { hinder people from } \\
\text { participating in } \\
\text { shaping the social } \\
\text { system of which } \\
\text { they are part? }\end{array}$} & $\begin{array}{l}\text { Practices that } \\
\text { suppress feedback } \\
\text { within the } \\
\text { organization }\end{array}$ & $\begin{array}{l}\text { No formal } \\
\text { mechanisms to } \\
\text { report up the } \\
\text { command chain, } \\
\text { lack of } \\
\text { whistleblower } \\
\text { system }\end{array}$ & $\begin{array}{l}\text { Practices that } \\
\text { suppress or rely on } \\
\text { the lack of } \\
\text { opportunity to } \\
\text { express the } \\
\text { communities' } \\
\text { opinion in relation } \\
\text { to our work }\end{array}$ & $\begin{array}{l}\text { No formal } \\
\text { mechanisms for } \\
\text { the communities to } \\
\text { give } \\
\text { opinion/influence } \\
\text { the business that } \\
\text { affects them }\end{array}$ \\
\hline & & $\begin{array}{l}\text { Practices that } \\
\text { suppress } \\
\text { employees' } \\
\text { influence on the } \\
\text { governance of the } \\
\text { organization }\end{array}$ & $\begin{array}{l}\text { No collective } \\
\text { bargain rights }\end{array}$ & $\begin{array}{l}\text { Practices that } \\
\text { suppress or rely on } \\
\text { the lack of } \\
\text { opportunity to } \\
\text { express the } \\
\text { communities' } \\
\text { opinion in relation } \\
\text { to political activity } \\
\text { in their community }\end{array}$ & $\begin{array}{l}\text { Reliance on } \\
\text { political regime } \\
\text { that engages in } \\
\text { suppression of free } \\
\text { speech, does not } \\
\text { have free elections, } \\
\text { etc. }\end{array}$ \\
\hline
\end{tabular}

On the basis of the insights from the case study, we agree with prior scholars (e.g., [7,24,75] that it is necessary to engage "external" stakeholders to achieve sustainable supply chains, including stakeholders with no direct economic link to the supply chain.

What stakeholders to engage is context-specific, but we propose that each organization asks itself who, i.e., what actor or individual, is needed to collaborate to achieve sustainable supply chains. The identification of essential stakeholders is adapted from Freeman's [76] definition of stakeholder as "any group or individual who can affect or is affected by the achievement of the organization's objectives". We also base this on the case study 
discussions and scholar's experience working with other organizations (see, e.g., [77,78]. A generalizable stakeholder map visualized within a system perspective is shown in Figure 5, which is a starting point for further mapping.

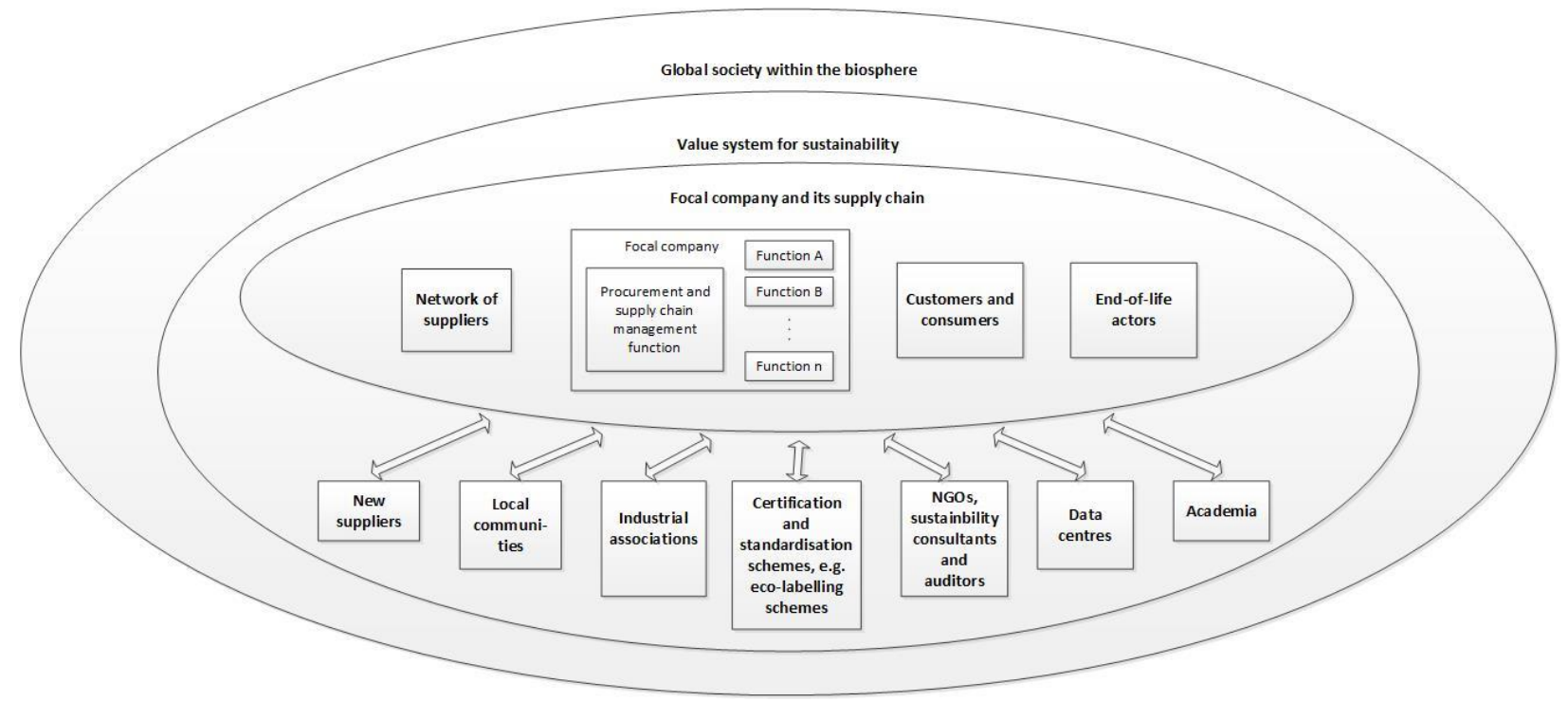

Figure 5. Starting map for further SSCM stakeholder mapping.

Who: Supply chain managers, procurers, key account managers, sustainability managers, product development managers, and external sustainability experts (dependent on the organizational structure).

Expected outcome and research proposition: Understanding the supply chain and stakeholders enables change within and across organizations. This step produces (1) map(s) of the current supply chain structure, flows, relationships, and an understanding of traceability gaps and related uncertainty, and (2) an understanding of critical stakeholders for achieving the vision.

\subsubsection{Step 4-Cocreate Strategies and Actions Intraorganizational Perspective}

What: The creative tension between the vision and the current reality "is meant to generate energy, like a rubber band stretched between two poles" [55]. We propose formulating what the company will likely offer in the future, with what value proposition, and within what business model. Managers need to understand how integrated management across different functions can contribute to this and the vision and how they need to collaborate, i.e., develop aligned strategies for functions, processes, and decision making. As in the case study, this can clarify how actions in the product development function relate to a changing business model and how this relates to sustainable supply chains. Strategically handling possible tradeoffs through cross-functional assessment of alternatives serves as a stepping stone to achieving the vision. With further learning and co-development of ideas across functions, the organization can see the large-scale use of new products and existing wasteful business models and handle tradeoffs from a vision of sustainability. One difficulty with SSCM is how to build long-term relationships and trust with suppliers when shifting to new technology. Relationships between supply chain members are essential for qualitative information and knowledge sharing. Additionally, relationship commitments are directly related to the exchange of strategic information within supply chains. Therefore, we recommend building relationships that are anchored by cross-functional discussions and built into cross-functional strategies.

This step is, thus, essential to overcome long-held corporate structures and routines that favor the status quo. 
Who: Senior-level sustainability team and key representatives from all functions of the organization.

Expected outcome and proposition: Cocreating strategies and actions enables integrated management. Outcomes include, but are not limited to, coherent strategies for how the company and its functional groups can progress towards the sustainable vision and, possibly, an appointed coordinator or team to manage progress.

Interorganizational Perspective

It is crucial that the benefits of taking a longer-term system's perspective, including proactive management toward sustainability, are realized by key suppliers. Therefore, we suggest creating settings in which the vision and strategic plan are shared with strategic suppliers. This includes sharing the definition of sustainability as the FSSD. This can be a continuous interaction to help enable organizational learning. Building competencies in system thinking among suppliers will initially explain new insight, which can then act as a catalyst for change and new benefits. Transparency with visions and plans and creating mutual interdependencies have been found to convert the plans into action [6] and overcome power imbalances between actors [79]. Long-term orientation toward shared objectives is a prerequisite for any effective collaboration. Deepened assessment and cocreation of solutions together with suppliers are recommended. It has been shown that, unless environmental problems are understood by actors in the supply chain, sharing valuable information is unlikely [80].

As stated in the former step, effective collaboration with suppliers requires the management of relationships [81-83]. Here, we see that organizations achieve and maintain a certain level of trust [84]. Trust was found to be crucial in the case study, where the longterm relationships with some suppliers were critical for starting the engagement in SSCM. Therefore, we propose including individuals at both the focal company and the suppliers where trust and good relationships already exist. Our findings are supported by studies on the functionality of social systems, in which trust was acknowledged to be an essential aspect of social cohesion [85]. It has also been shown that, with the increasing complexity of social systems, individuals increasingly need to rely on and trust each other [86,87].

By combining the above, we suggest that a critical strategy for implementing SSCM is to start working with first-tier suppliers identified as essential collaborators to achieve the vision and to do so from established relationships between individuals. This work with suppliers can require external sustainability experts (e.g., a consultancy with a local presence) to overcome knowledge and cultural barriers. It can also mean that the focal company needs to invest in continuous workshops and suppliers to agree upon visions, strategies, and long- and short-term objectives, i.e., this is not a one-time approach to a new project but, instead, an interactive process.

Altogether, the proposed SSCM process represents an ongoing interaction with supply chain members. Thus, it is possible to build "a learning supply chain" by continuously sharing the focal company's sustainability vision and culture while integrating this into new organizations. This organizational learning and integrated management aim to improve overall sustainability performance [88-90].

Who: Supply chain managers, appointed individuals from procurement staff, representatives of suppliers, and, if needed, sustainability experts.

Expected outcome and proposition: Cocreating strategies and interorganizational actions increase mutual trust, align strategies, and align objectives throughout the supply chain.

\section{Conclusions}

Our case-based research involved the organizational change process of a lighting company that proactively wants to become a global leader in sustainability within their industry by applying a science-based framework for strategic sustainable development (FSSD). We outlined a process implementing SSCM by synthesizing empirical insights from the case study while also building on prior research from organizational learning and the 
evolving SSCM literature. We sought to provide actionable support to a company with a vision to become a leader in sustainable lighting. We did this while also creating relevant insights for future exploration, i.e., to provide value to other organizations and the field of research involving sustainability and supply chain management. Our case-based study included outlining support by a generalizable implementation process for SSCM. First, the integration of sustainability into SSCM needed to be anchored within the core vision, mission, and organizational culture of a focal company $[4,6,37]$. Secondly, the successful implementation of SSCM necessitated continued organizational learning [24].

Contributions of this study include a response to calls for case-based insights [15], increasing the understanding of the implementation process of SSCM, and recognizing it as a transformational process that includes organizational learning [10]. In addition, we fill gaps in the literature and address calls for SSCM research to take a systems perspective [15,91-93], including a full socioecological perspective with a clear definition of social sustainability [13]. Outcomes of this study can help shed new light on social and ecological sustainability as desirable objectives; in doing so, the field moves away from a myopic, traditional economic-based logic [7,12]. Lastly, we contribute to sustainable business practice research by introducing social and ecological sustainability models and their integration into the SSCM field.

We build on the work done by Oelze et al. [24] in exploring the relationship between SSCM and organizational learning and the channels through which organizational learning can be achieved. We add to and contrast this by applying an in-depth, multiple-year case-based approach to studying the leadership of an organization and its values, as well as exploring the foundations for integrating successful SSCM implementation practices. By applying systems thinking and a framework for strategic sustainable development (FSSD), we find support in prior claims by [55] that this can lead to more balanced, long-term value creation for systems inside and outside the organization. We also find support for integrated management leading to new benefits across business functions and supply chains [90]. We propose a collaborative approach to problem-solving, the development of solutions supporting internal benefits to the organization, and the alignment of mission and vision to support sustainable supply chains. By doing so, we are a part of the emerging trend in research involving SSCM that seeks to move the field from focusing on existing supply chains' abilities to become less unsustainable, i.e., efficient, to creating more effective and truly sustainable supply chains.

In this study, we take a normative stance that sustainable development is desirable. Applying a case-based research methodology, we wanted to learn through our own experiences and those of other project stakeholders about the drivers and barriers to change when creating a vision of a sustainable future. We explored the feasibility of a stepwise process from a focal company, leadership team, and supply chain perspective. In doing so, we tried to consider a multi-stakeholder perspective. We recognize that the work this company has to do is ongoing. There is a need for continued longitudinal interactions with actors of the supply chain and other stakeholders, and this kind of fieldwork and change management can take years.

Future research and development of the prototype process proposed in this study will be necessary to further understand sustainability in supply chain management and forthcoming changes in supply chain dynamics. The continued development of the implementation process and further study of complex interactions, including other stakeholders outside the supply chain, will be critical to understanding and addressing the dynamic and complex nature of integrating environmental and social sustainability in supply chains. Engaging and collaborating with stakeholders will bring increased complexity and multiple organizational values, as well as a call for a culture of learning [88]. It will also demand trust between actors built from ongoing, long-term relationships. Thus, innovative companies with a changing supply base will find challenges when implementing SSCM, and this area of research will provide rich insights. 
A final challenge for future research involves more, not less field-based studies. Managers are naturally wary of direct interference in their supply chain; thus, conducting case study research will not be easy. We provide a way to overcome some of this apprehension with an evidence-based approach to new insights and benefits for any company that builds on prior work in the field, this study, and future case studies. These insights will help overcome sustainability and supply chain obstacles, enabling collaborative organizational learning engagements with researchers and stakeholders. As a result, an increased number of researchers will be active participants in finding new solutions for sustainability problems. Touboulic and Walker [15] support this call for more researcher involvement in case-based studies. They claim that "action research as an engaged and relational research approach provides the opportunity to test and build new theory in sustainable supply chain management that draws from the rich empirical settings and its relevance to practitioners". To this end, we agree that there is a considerable need for more action-based case study research to support sustainable organizational activities while also advancing scholarly work in this field. SSCM provides a collaborative opportunity for researchers and practitioners that cannot be overlooked in future research.

Author Contributions: Conceptualization, C.B. and G.B.; methodology, C.B.; data curation, C.B.; writing original draft, C.B.; writing, C.B. and R.S.; review and editing, C.B., R.S. and G.B.; visualization C.B. and R.S. All authors have read and agreed to the published version of the manuscript.

Funding: This research received no external funding. The APC was funded by the authors' universities.

Informed Consent Statement: Informed consent was obtained from all subjects involved in the study.

Acknowledgments: Financial support from the Knowledge Foundation in Sweden is gratefully acknowledged. The authors sincerely thank the industrial research partner, interviewees, and workshop participants.

Conflicts of Interest: The authors declare no conflict of interest.

\section{References}

1. UN Global Compact. Global Corporate Sustainability Report 2013. UN Glob. Compact. Rep. 2013, 5, 1-28. [CrossRef]

2. Carter, C.R. Purchasing social responsibility and firm performance: The key mediating roles of organizational learning and supplier performance. Int. J. Phys. Distrib. Logist. Manag. 2005, 35, 177-194. [CrossRef]

3. Willard, B. The Sustainability Champion's Guidebook: How to Transform Your Company; New Society Publishers: Gabriola, BC, Canada, 2009.

4. Broman, G.I.; Robèrt, K.-H. A framework for strategic sustainable development. J. Clean. Prod. 2017, 140, 17-31. [CrossRef]

5. Berns, M.; Townend, A.; Khayat, Z.; Balagopal, B.; Reeves, M.; Hopkins, M.; Kruschwitz, N. The business of sustainability. Results and insights from the first annual MIT Sloan Management Review Global Sustainability Review. MIT Sloan Manag. Rev. 2009, 1-32. Available online: https://sloanreview.mit.edu/projects/the-business-of-sustainability/ (accessed on 10 June 2021).

6. Meehan, J.; Bryde, D. Sustainable Procurement Practice. Bus. Strategy Environ. 2011, 20, 94-106. [CrossRef]

7. Pagell, M.; Shevchenko, A. Why Research in Sustainable Supply Chain Management Should Have No Future. J. Supply Chain Manag. 2014, 50, 44-55. [CrossRef]

8. Sroufe, R.; Melnyk, S.A. Developing Sustainable Supply Chains: Management Insights, Issues, and Tools: Volume I Foundations; Business Expert Press: New York, NY, USA, 2017.

9. Beske, P. Dynamic capabilities and sustainable supply chain management. Int. J. Phys. Distrib. Logist. Manag. 2012, 42, 372-387. [CrossRef]

10. Touboulic, A.; Walker, H. Theories in sustainable supply chain management: A structured literature review. Int. J. Phys. Dist. Log. Manag. 2015, 45, 16-42. [CrossRef]

11. Vargas, J.R.C. Sustainable supply chain management capabilities: A review from the resource-based view, the dynamic capabilities and stakeholder theories. Lat. Am. J. Manag. Sustain. Dev. 2014, 1, 323-343. [CrossRef]

12. Montabon, F.; Pagell, M.; Wu, Z. Making Sustainability Sustainable. J. Supply Chain Manag. 2016, 52, 11-27. [CrossRef]

13. Nakamba, C.C.; Chan, P.W.; Sharmina, M. How does social sustainability feature in studies of supply chain management? A review and research agenda. Supply Chain Manag. 2017, 22, 522-541. [CrossRef]

14. Carter, C.R.; Washispack, S. Mapping the Path forward for Sustainable Supply Chain Management: A Review of Reviews. J. Bus. Logist. 2018, 39, 242-247. [CrossRef]

15. Touboulic, A.; Walker, H. A relational, transformative and engaged approach to sustainable supply chain management: The potential of action research. Hum. Relat. 2016, 69, 301-343. [CrossRef] 
16. Senge, P.M.; Carstedt, G. Innovating Our Way to the Next Industrial Revolution. MIT Sloan Manag. Rev. 2001, 42, 24-38.

17. Lozano, R. Creativity and Organizational Learning as Means to Foster Sustainability: Creativity and Organizational Learning. Sustain. Dev. 2014, 22, 205-216. [CrossRef]

18. March, J.G. Exploration and Exploitation in Organizational Learning. Organ. Sci. 1991, 2, 71-87. [CrossRef]

19. López, S.P.; Peón, J.M.M.; Ordás, C.J.V. Human Resource Management as a Determining Factor in Organizational Learning. Manag. Learn. 2006, 37, 215-239. [CrossRef]

20. Jamali, D. Insights into triple bottom line integration from a learning organization perspective. Bus. Process. Manag. J. 2006, 12, 809-821. [CrossRef]

21. Nattrass, B.; Altomare, M. The Natural Step for Business: Wealth, Ecology \& the Evolutionary Corporation; New Society Publishers: Gabriola, BC, Canada, 2013.

22. Siebenhüner, B.; Arnold, M. Organizational learning to manage sustainable development. Bus. Strategy Environ. 2007, 16, 339-353. [CrossRef]

23. Doppelt, B. Leading Change toward Sustainability: A Change-Management Guide for Business, Government and Civil Society; Routledge: Oxfordshire, UK, 2017.

24. Oelze, N.; Hoejmose, S.U.; Habisch, A.; Millington, A. Sustainable Development in Supply Chain Management: The Role of Organizational Learning for Policy Implementation: The Role of Organizational Learning for RSCM Policy Implementation. Bus. Strategy Environ. 2016, 25, 241-260. [CrossRef]

25. Robinson, J.B. Future under glass-A recipe for people who hate to predict. Futures 1990, 22, 820-843. [CrossRef]

26. Dreborg, K.H. Essence of back-casting. Futures 1996, 28, 813-828. [CrossRef]

27. Robèrt, K.-H. Tools and concepts for sustainable development, how do they relate to a general framework for sustainable development, and to each other? J. Clean. Prod. 2000, 8, 243-254. [CrossRef]

28. Missimer, M.; Robèrt, K.-H.; Broman, G. A strategic approach to social sustainability-Part 2: A principle-based definition. J. Clean. Prod. 2017, 140, 42-52. [CrossRef]

29. Carter, C.R.; Rogers, D.S. A framework of sustainable supply chain management: Moving toward new theory. Int. J. Phys. Distrib. Logist. Manag. 2008, 38, 360-387. [CrossRef]

30. Seuring, S.; Müller, M. From a literature review to a conceptual framework for sustainable supply chain management. J. Clean. Prod. 2008, 16, 1699-1710. [CrossRef]

31. Beske, P.; Land, A.; Seuring, S. Sustainable supply chain management practices and dynamic capabilities in the food industry: A critical analysis of the literature. Int. J. Prod. Econ. Sustain. Food Supply Chain Manag. 2014, 152, 131-143. [CrossRef]

32. Rajeev, A.; Pati, R.K.; Padhi, S.S.; Govindan, K. Evolution of sustainability in supply chain management: A literature review. J. Clean. Prod. 2017, 162, 299-314. [CrossRef]

33. Pettigrew, A.M. Management Research after Modernism. Br. J. Manag. 2001, 12, S61-S70. [CrossRef]

34. Van De Ven, A.H.; Johnson, P.E. Knowledge for Theory and Practice. Acad. Manag. Rev. 2006, 31, 802-821. [CrossRef]

35. Senge, P.M.; Lichtenstein, B.B.; Kaeufer, K. Collaborating for systemic change. MIT Sloan Manag. Rev. 2007, 48, 44-53.

36. Doppelt, B. Leading Change toward Sustainability; Greenleaf Publishing: Sheffield, UK, 2003.

37. Sroufe, R. Integration and organizational change towards sustainability. J. Clean. Prod. 2017, 162, 315-329. [CrossRef]

38. Eisenhardt, K.M. Building Theories from Case Study Research. Acad. Manag. Rev. 1989, 14, 532-550. [CrossRef]

39. Miles, M.B.; Huberman, A.M. Qualitative Data Analysis: An Expanded Sourcebook; SAGE: Los Angeles, CA, USA, 1994.

40. Yin, R.K. Case Study Research: Design and Methods, Applied Social Research Methods Series; SAGE Publications Inc.: Thousand Oaks, CA, USA, 2003.

41. Danermark, B.; Ekström, M.; Jakobsen, L.; Karlsson, J. Att Förklara Samhället; Studentlitteratur: Lund, Sweden, 2003.

42. Coughlan, P.; Coghlan, D. Action research for operations management. Int. J. Oper. Prod. Manag. 2002, 22, 220-240. [CrossRef]

43. Simons, H. Case Study Research in Practice; SAGE Publications: Thousand Oaks, CA, USA, 2009.

44. Hertzum, M. Images of Usability. Int. J. Hum. Comput. Interact. 2010, 26, 567-600. [CrossRef]

45. Schubert, E.F.; Gessmann, T.; Kim, J.K. Light Emitting Diodes. In Kirk-Othmer Encyclopedia of Chemical Technology; John Wiley \& Sons, Inc.: Hoboken, NJ, USA, 2000.

46. Mottier, P. LED for Lighting Applications; John Wiley \& Sons: Hoboken, NJ, USA, 2010.

47. Lim, S.-R.; Kang, D.; Ogunseitan, O.A.; Schoenung, J.M. Potential Envionrmental Impacts of Light-Emitting Diodes (LEDs): Metallic REsources, Toxicity, and Hazardous Waste Classification. Environ. Sci. Technol. 2011, 45, 320-327. [CrossRef]

48. Ogunseitan, O.A.; Schoenung, J.M.; Saphores, J.D.M.; Shapiro, A.A. The electronics revolution: From E-wonderland to Ewasteland. Science 2009, 326, 670-671. [CrossRef]

49. Lim, S.-R.; Schoenung, J.M. Human health and ecological toxicity potentials due to heavy metal content in waste electronic devices with flat panel displays. J. Hazard. Mater. 2010, 177, 251-259. [CrossRef]

50. Cordell, D. The Story of Phosphorus: Sustainability Implications of Global Phosphorus Scarcity for Food Security. Ph.D. Thesis, Linköping University, Linköping, Sweden, 2010.

51. Neset, T.S.S.; Cordell, D. Phosphorus and Global Food Security: A Synthesis. Proceedings from the International Workshop on Phosphorus and Global Food Security 24th-26th February, 2010; Linköping University Electronic Press: Linköping, Sweden, 2010.

52. Ragnarsdottir, K.V.; Sverdrup, H.U.; Koca, D. Challenging the planetary boundaries I: Basic principles of an integrated model for phosphorous supply dynamics and global population size. Appl. Geochem. 2011, 26, S303-S306. [CrossRef] 
53. Koninklijke Philips Electronics NV. Phosphor-A Critical Component in Fluoresecnt Lamps. 2011. Available online: http://www. usa.lighting.philips.com/pwc_li/us_en/lightcommunity/trends/phosphor/assets/philips_reo_brochure_p-6281.pdf (accessed on 1 July 2021).

54. Thompson, A.W.; Ny, H.; Lindahl, P.; Broman, G.; Severinsson, M. Benefits of a Product Service Approach for Long-Life Products: The Case of Light Tubes; CIRP IPS2: Linköping, Sweden, 2010.

55. Senge, P.; Hamilton, H.; Kania, J. The Dawn of System Leadership. Stanf. Soc. Innov. Rev. 2015, 13, 26-33.

56. Shrivastava, P.; Hart, S. Creating Sustainable Corporations. In Business Strategy E the Environment; John Wiley \& Sons, Inc.: Hoboken, NJ, USA, 1995; Volume 4, pp. 154-165.

57. Elkington, J. Cannibals with Forks: The Triple Bottom Line of 21st Century Business; Capstone: Oxford, UK, 1997.

58. Pagell, M.; Wu, Z. Builiding a more complete theory of sustainable supply chain management using case studies of 10 exemplars. J. Supply Chain Manag. 2009, 45, 37-56. [CrossRef]

59. Senge, P. The fifth discipline. In The Art and Practice of the Learning Organization; Doubleday: New York, NY, USA, 1990.

60. O'Connor, J.; McDermott, I. The Art of System Thinking: Essential Skills for Creativity and Problem Solving; Thorsons Publish Co.: San Francisco, CA, USA, 1997.

61. Bui, H.; Baruch, Y. Creating learning organizations: A systems perspective. Learn. Organ. 2010, 17, 208-227. [CrossRef]

62. Rosner, W.J. Mental models for sustainability. J. Clean. Prod. 1995, 3, 107-121. [CrossRef]

63. Appelbaum, S.H.; Goransson, L. Transformational and adaptive learning within the learning organization: A framework for research and application. Learn. Organ. 1997, 4, 115-128. [CrossRef]

64. Meadows, D. Leverage points: Places to intervene in a system. Sustain. Inst. 1999, 3, 19.

65. Maon, F.; Lindgreen, A.; Swaen, V. Designing and Implementing Corporate Social Responsibility: An Integrative Framework Grounded in Theory and Practice. J. Bus. Ethics 2009, 87, 71-89. [CrossRef]

66. Schein, E.H. The mechanisms of change. Plan. Chang. 1969, 2, 98-107.

67. Lessard, D.R.; Amsden, A.H. The Multinational Enterprise as a Learning Organization. In Contemporary Economic Issues; Cohen, D., Ed.; Palgrave Macmillan: London, UK, 1998; pp. 65-81.

68. Mohammed, S.; Dumville, B.C. Team mental models in a team knowledge framework: Expanding theory and measurement across disciplinary boundaries. J. Organ. Behav. 2001, 22, 89-106. [CrossRef]

69. Argyris, C. Double Loop Learning in Organizations. Harv. Bus. Rev. 1977, 5595, 115-125.

70. Griego, O.V.; Geroy, G.D.; Wright, P.C. Predictors of learning organizations: A human resource development practitioner's perspective. Learn. Organ. 2000, 7, 5-12. [CrossRef]

71. Collins, J.C.; Porras, J.I. Building Your Company's Vision. Harv. Bus. Rev. 1996, 74, 65-78.

72. Senge, P.M. The fifth discipline. Meas. Bus. Excell. 1997, 1, 46-51. [CrossRef]

73. Senge, P. Creating desired futures in a global economy. Reflections 2003, 5, 1-12.

74. Mol, A.P.J. Transparency and value chain sustainability. J. Clean. Prod. 2015, 107, 154-161. [CrossRef]

75. Burchell, J.; Cook, J. Stakeholder dialogue and organisational learning: Changing relationships between companies and NGOs. Bus. Ethics Eur. Rev. 2007, 17, 35-46. [CrossRef]

76. Freeman, R.E. Strategic Management: A Stakeholder Approach; Pitman: Boston, MA, USA, 1984.

77. Bratt, C.; Hallstedt, S.; Robért, K.-H.; Oldmark, J.; Broman, G. Assessment of eco-labelling criteria development from a strategic sustainability perspective. J. Clean. Prod. 2011, 19, 1631-1638. [CrossRef]

78. Bratt, C.; Hallstedt, S.; Robèrt, K.-H.; Broman, G.; Oldmark, J. Assessment of criteria development for public procurement from a strategic sustainability perspective. J. Clean. Prod. 2013, 52, 309-316. [CrossRef]

79. Mentzer, J.T.; Min, S.; Zacharia, Z.G. The nature of interfirm partnering in supply chain management. J. Retail. 2000, 76, 549-568. [CrossRef]

80. Barratt, M.; Oke, A. Antecedents of supply chain visibility in retail supply chains: A resource-based theory perspective. J. Oper. Manag. 2007, 25, 1217-1233. [CrossRef]

81. Handfield, R.B.; Bechtel, C. The role of trust and relationship structure in improving supply chain responsiveness. Ind. Mark. Manag. 2002, 31, 367-382. [CrossRef]

82. Handfield, R.; Sroufe, R.; Walton, S. Integrating Environmental Management and Supply Chain Strategies; John Wiley \& Sons, Ltd.: Hoboken, NJ, USA, 2005.

83. Preuss, L. Rhetoric and Reality of Corporate Greening: A View from the Supply Chain Management Function. Bus. Strategy Environ. 2005, 14, 123-139. [CrossRef]

84. Petersen, K.J.; Ragatz, G.L.; Monczka, R.M. An Examination of Collaborative Planning Effectiveness and Supply Chain Performance. J. Supply Chain Manag. 2005, 41, 14-25. [CrossRef]

85. Missimer, M.; Robèrt, K.-H.; Broman, G. A strategic approach to social sustainability—Part 1: Exploring the social system. J. Clean. Prod. 2017, 140, 32-41. [CrossRef]

86. Meijboom, F.L.B.; Visak, T.; Brom, F.W.A. From Trust to Trustworthiness: Why Information Is Not Enough in the Food Sector. J. Agric. Environ. Ethics 2006, 19, 427-442. [CrossRef]

87. Meijboom, F.L.B. Problems of Trust: A Question of Trustworthiness: An Ethical Inquiry of Trust and Trustworthiness in the Context of the Agricultural and Food Sector; Utrecht University: Utrecht, The Netherlands, 2008. 
88. Harms, D.; Hansen, E.G.; Schaltegger, S. Strategies in Sustainable Supply Chain Management: An Empirical Investigation of Large German Companies: Strategies in Sustainable Supply Chain Management. Corp. Soc. Responsib. Environ. Manag. 2013, 20, 205-218. [CrossRef]

89. Beske, P.; Seuring, S. Putting sustainability into supply chain management. Supply Chain Manag. Int. J. 2014, 19, 322-331. [CrossRef]

90. Sroufe, R. Integrated Management: How Sustainability Creates Value for Any Business; Emerald Group Publishing: Bingley, UK, 2018.

91. Ashby, A.; Leat, M.; Hudson-Smith, M. Making connections: A review of supply chain management and sustainability literature. Supply Chain Manag. Int. J. 2012, 17, 497-516. [CrossRef]

92. Hoejmose, S.U.; Adrien-Kirby, A.J. Socially and environmentally responsible procurement: A literature review and future research agenda of a managerial issue in the 21st century. J. Purch. Supply Manag. 2012, 18, 232-242. [CrossRef]

93. Winter, M.; Knemeyer, A.M. Exploring the integration of sustainability and supply chain management: Current state and opportunities for future inquiry. Int. J. Phys. Distrib. Logist. Manag. 2013, 43, 18-38. [CrossRef] 